\title{
An Exploration on Pilling Attitudes of Cotton Polyester Blended Single Jersey Knit Fabric After Mechanical Singeing
}

\author{
Shamima Akter Smriti, Md. Azharul Islam \\ Department of Textile Engineering, Daffodil International University, Dhaka, Bangladesh
}

Email address:

smriti.te@daffodilvarsity.edu.bd (S. A. Smriti), maisalim2008@daffodilvarsity.edu.bd (Md. A. Islam)

To cite this article:

Shamima Akter Smriti, Md. Azharul Islam. An Exploration on Pilling Attitudes of Cotton Polyester Blended Single Jersey Knit Fabric After Mechanical Singeing. Science Innovation. Vol. 3, No. 1, 2015, pp. 18-21. doi: 10.11648/j.si.20150301.12

\begin{abstract}
This article presents the pilling attitude of different cotton polyester ratio blended yarn single jersey knitting fabric after mechanical singeing. Four different blended yarn $(80 \%$ cotton $20 \%$ polyester, $60 \%$ cotton $40 \%$ polyester, $52 \%$ cotton $48 \%$ polyester, $35 \%$ cotton $65 \%$ polyester) were selected and knitted in two different $180 \& 120 \mathrm{GSM}$, containing $10 \mathrm{~kg}$ for each composition for GSM variation. All the samples were singed first on both sides of fabric, processed with scouring and bleaching and finally degree of pilling was evaluated and compared with the unsigned processed samples. The target was to compare the pilling tendency of different blends before and after singeing process. Pilling test was accomplished by ISI pilling box machine obeying ISO 12945-1:2000 standard method where eight specimens were tumbled in pilling box for 11,500 number of revolutions. Finally it was found that mechanically singed samples show good pilling grade (3-4) than that of without singed samples (1-2) and higher Presence of polyester fibre on blended yarn affects the pilling attitude of the fabric to a down grade for both higher and lower GSM. It was also perceived that higher GSM fabrics have more pilling tendency than lower GSM for each without singed and after singed samples.
\end{abstract}

Keywords: Mechanical Singeing, Pilling Attitude, Blended Yarn

\section{Introduction}

Singeing is carried out to remove the hairy or protruding fibres of both knit and woven fabrics. Mechanical singeing is widely used for woven fabrics and now a day it is also using for knit fabrics where chemical singeing (enzyme treatment) is very popular for its easy processing with measurable efficiency (1) to eliminate pills of fabric surface. Chemical singeing is used for $100 \%$ cotton fabric because enzyme digests the cellulose which causes the reduction of floating or protruding fibres. Because of the inactivity of enzyme against polyester, the use of mechanical singeing in cotton polyester blended yarn is increasing for better surface smoothness.

Y. Sabina et al. found on their research work that pilling properties of the single lacoste fabric shows higher pilling than double lacoste conversely single jersey fabric shows lower resistance to pilling and this test was followed by ISO 12945-1:2000 method on ISI pilling box machine.(2)

L. Long et al. (3) worked with cashmere knitted fabrics and observed the pilling rates of the fabrics for different colors and spinning methods. Samples were tested using
ICI's Pilling Box and the number of the pills formed and type of fuzz for each sample were measured using an electronic balance. The pilling rate of cashmere knitted fabric of mule yarn originated higher than that of ring yarn.

Özdil et al. linked knitted fabrics from compact spun yarns by means of classic ring spun yarns and stated that knitted fabric from compact yarns validated enhanced pilling attitude. (4)

Gintis and Mead (5) confirmed in their work that pilling attitude is prejudiced by not only the structure of the yarn and fabric but also by the fiber properties, e.g. tensile strength, percent elongation, flex abrasion, bending rigidity, fiber titer, shape of fiber cross-section and friction.

Campos and Bechtold (6) also established a mathematical model to evaluate fiber-fiber friction and that gave an indication of the pilling properties of man-made cellulosic knitted fabrics.

The pilling performance and abrasion resistance of plain knitted fabric from chenille yarns was studied by Nergis \& Candan (7) and outcomes presented that yarn properties (component yarn count, pile length) and laundering or dry- 
cleaning do not affect the pilling performance and abrasion resistance of dry relaxed fabrics.

In a study, Mavruz \& Ogulata (8) worked with jersey, rib and interlock fabrics knitted from ring and compact yarns in $\mathrm{Ne} 30$ and $\mathrm{Ne} 40$ and examined pilling properties. But, it wasn't observed the significant difference between the pilling properties of fabrics produced from different fibre percentages of blended yarn.

Baird et al. (9) also stated that rapid washing increases pilling tendency.

Omeroğlu \& Ulku (10) stated on their paper that compact yarns woven fabrics had higher pilling resistance as compared to woven from ring yarns. They observed more hairiness on surface in case of ring yarn woven fabrics. Furthermore, from abrasion resistance test results, it was established that fabrics woven from compact yarns led to a $19.3 \%-43.0 \%$ less weight loss compared to ring yarn woven fabrics.

\section{Material \& Method}

As it is known that, pilling is a condition that arises in wear because of the little pills of entangled fibre that are formed by a rubbing action on loose fibre present on the surface of the fabric. Pilling is originally a fault $\&$ the deteriorated surface produced for pilling is undesirable for the consumer. The rate of pilling depends on the fibre, yarn, fabric properties. The presence of manmade fibre into fabric has aggravated its seriousness. The pilling property is more severe for the fabric produced from blended (cotton/poly) yarn. To conduct this work some cotton/polyester blended yarn fabric were used. Total eight sample of different composition fabric were taken. The GSM of four samples is 120 , and other four is 180 , each sample was produced $10 \mathrm{~kg}$ on Junny Long knitting machine (origin: Taiwan). At that moment each sample was divided into two groups having $5 \mathrm{~kg}$ in every one. One group of samples was carried out without mechanical singeing and other with mechanical singeing.

Total effort was carried out through the following process for both without singed and with singed samples:

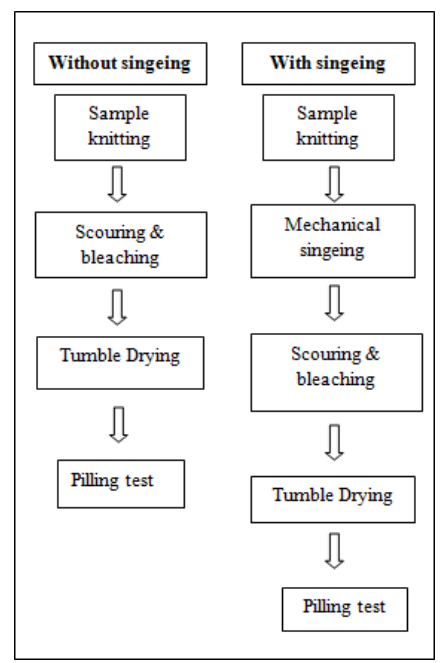

Figure 1. Process flow chart for without singeing and with singeing samples
The sample specification with scouring \& bleaching recipe is tabled below:

Table 1. Sample specification

\begin{tabular}{llll}
\hline Fabric composition & GSM & Fabric composition & GSM \\
\hline $80 \%$ cotton $20 \%$ polyester & 180 & $80 \%$ cotton $20 \%$ polyester & 120 \\
$60 \%$ cotton $40 \%$ polyester & 180 & $60 \%$ cotton $40 \%$ polyester & 120 \\
$52 \%$ cotton $48 \%$ polyester & 180 & $52 \%$ cotton $48 \%$ polyester & 120 \\
$35 \%$ cotton $65 \%$ polyester & 180 & $35 \%$ cotton $65 \%$ polyester & 120 \\
\hline
\end{tabular}

Table 2. Scouring \& bleaching recipe

\begin{tabular}{ll}
\hline Parameters & Amount \\
\hline Wetting agent & $0.65 \mathrm{~g} / 1$ \\
Anti-creasing agent $(\mathrm{ACN})$ & $0.65 \mathrm{~g} / 1$ \\
Leveling agent(CL-225) & $0.50 \mathrm{~g} / 1$ \\
Hydrogen per oxide $\left(\mathrm{H}_{2} \mathrm{O}_{2}\right)$ & $2.5 \mathrm{~g} / 1$ \\
Sodium Hydroxide $(\mathrm{NaOH})$ & $1.5 \mathrm{~g} / 1$ \\
Stabilizer & $0.25 \mathrm{~g} / 1$ \\
Sequestering agent $(\mathrm{SQ} 114)$ iron base & $1 \mathrm{~g} / 1$ \\
Time \& Temperature & $30 \mathrm{~min}, 98^{\circ} \mathrm{C}$ \\
\hline
\end{tabular}

\subsection{Singeing Specification}

The singeing operation was done by both side gas singeing machine (double burner). The specification of the machine:

Company: Poong kwang machine, Origin: Korea, working width: $2400 \mathrm{~mm}$.

The fabric is singed in the machine at a speed of $35 \mathrm{~m} / \mathrm{min}$ $\&$ flame height $8 \mathrm{~mm}$.

\subsection{Pilling Procedure}

After preparing the final samples, all of them were carried out for the pilling test. The pilling test was performed according to ISO 12945-1:2000.

It needs to condition the specimen before pilling. It was conditioned in standard temperature $20^{\circ} \mathrm{C}+2^{\circ} \mathrm{C}$ and relative humidity $65 \%+2 \%$ for at least $16 \mathrm{hrs}$, the test is carried out in same atmosphere.

All eight specimen from the sample are then placed on the same pill testing box, the tubes are tumbled in the box for 11,500 number of revolution.

\subsection{Pilling Assessment}

The samples are then given a rating of between 1 to 5 by using photographic assessment. The visual assessment table is given below: [ISO 12945-1] 
Table 3. Pilling assessment

\begin{tabular}{|c|c|}
\hline Grade & Description \\
\hline 5 & No change. \\
\hline 4 & Slight surface fuzzing and/or partially formed pills. \\
\hline 3 & $\begin{array}{l}\text { Moderate surface fuzzing and/or moderate pilling. Pills of } \\
\text { varying size and density partially covering the specimen } \\
\text { surface. }\end{array}$ \\
\hline 2 & $\begin{array}{l}\text { Distinct surface fuzzing and/or distinct pilling. pills of varying } \\
\text { size and density covering a large proportion of the specimen } \\
\text { surface. }\end{array}$ \\
\hline 1 & $\begin{array}{l}\text { Dense surface fuzzing and/or severe pilling. pills of varying } \\
\text { size and density covering a whole of the specimen surface. }\end{array}$ \\
\hline
\end{tabular}

\section{Results and Discussions}

Table 4. Pilling grade of different fabrics without singeing

\begin{tabular}{llll}
\hline For 120 GSM & & & \\
\hline Fabric consumption & GSM & $\begin{array}{l}\text { Pilling } \\
\text { (without singeing) }\end{array}$ & $\begin{array}{l}\text { grade } \\
\text { (after } \\
\text { singeing) }\end{array}$ \\
\hline $80 \% \mathrm{C}+20 \% \mathrm{P}$ & 120 & 2 & $3-4$ \\
$60 \% \mathrm{C}+40 \% \mathrm{P}$ & 120 & 2 & $3-4$ \\
$48 \% \mathrm{C}+52 \% \mathrm{P}$ & 120 & $1-2$ & 3 \\
$35 \% \mathrm{C}+65 \% \mathrm{P}$ & 120 & 1 & $2-3$ \\
\hline
\end{tabular}

Table 5. Pilling grade of different fabrics after singeing

\begin{tabular}{llll}
\hline For 180 GSM & & Pilling grade & $\begin{array}{l}\text { Pilling grade } \\
\text { (after } \\
\text { singeing) }\end{array}$ \\
\hline Fabric consumption & GSM & singeing) & 3 \\
\hline $80 \% \mathrm{C}+20 \% \mathrm{P}$ & 180 & 2 & 3 \\
$60 \% \mathrm{C}+40 \% \mathrm{P}$ & 180 & $1-2$ & $2-3$ \\
$48 \% \mathrm{C}+52 \% \mathrm{P}$ & 180 & 1 & 2 \\
$35 \% \mathrm{C}+65 \% \mathrm{P}$ & 180 & 1 & \\
\hline
\end{tabular}

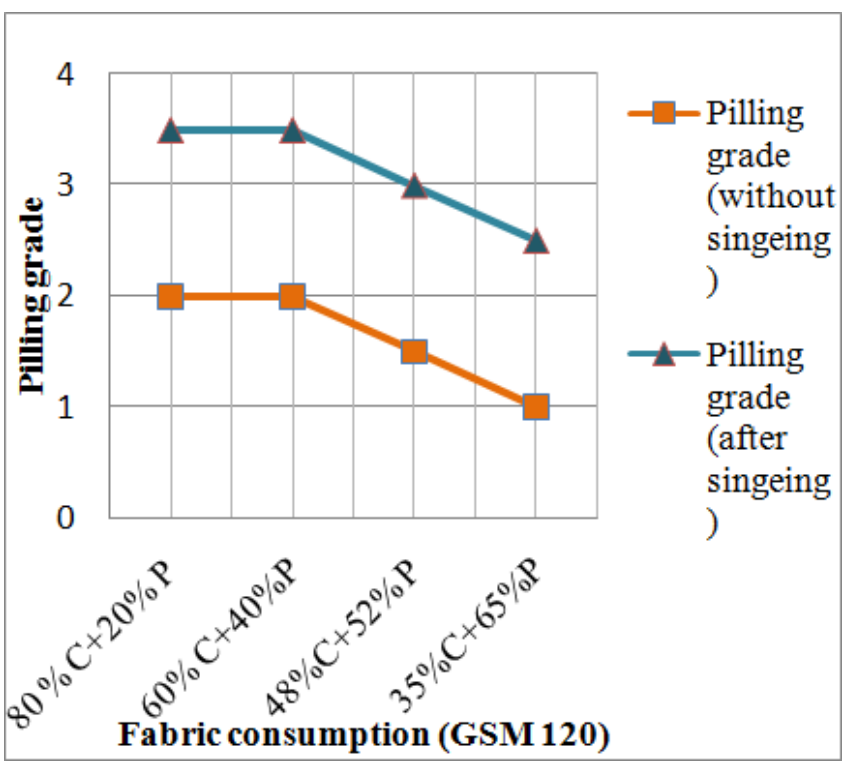

Figure 2. Pilling grade of different singed and non-singed samples at 120 GSM

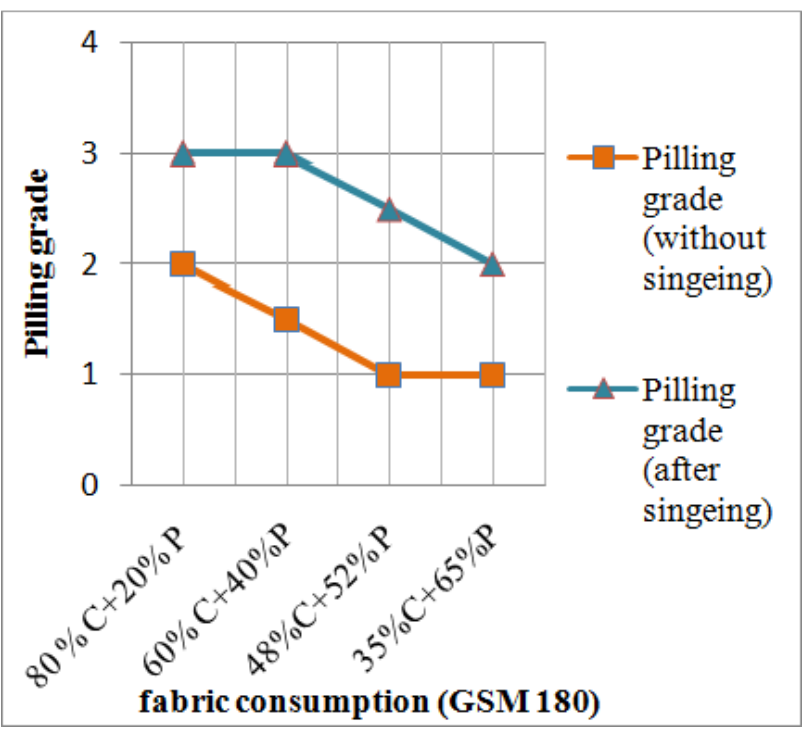

Figure 3. Pilling grade of different singed and non-singed samples at 180 GSM

From table-4, table-5, figure-2 \& figure-3 confirms that for both GSM and any blend percentages, after singeing the pilling properties of the samples remain better than the fabrics of without singeing. It was also detected that with the increment of polyester percentage on yarn pilling tendency of the sample increases which confirms the lower grade of the samples. Furthermore, higher GSM samples have lower pilling grade whereas lower GSM fabrics have higher grade which endorses the better pilling quality of lower GSM samples than that of higher GSM. It happens for presence of higher number of fibres in higher GSM samples than lower GSM samples.

\section{Conclusion}

This research work mainly emphasizes on the effect of polyester cotton blended yarn on pilling attitude of single jersey knitted fabrics after mechanical singeing. With this, the change in pilling attitude was also observed with the change of GSM of the fabrics. Completion of the research work ended with the resulting findings:

Mechanical singeing process imports well pilling attitude to all the samples. In case of lower GSM fabrics the pilling attitude was better than higher GSM fabrics.

It was also detected that with the increment of polyester fibre on blended yarn pilling attitude falls down grade for both singed and non-singed samples. It means that mechanical singeing may be recommended to elevate the pilling grade and high GSM of fabrics with blended yarn has more pilling tendency.

\section{Acknowledgement}

The authors gratefully want to acknowledge the help \& support from Mrs. Kaniz Fatema, Assistant General Manager (Lab and R\&D), Micro Fibre Group, Fatulla, Narayanganj, Bangladesh. 


\section{References}

[1] M.A. Hannan, M. Zakaria, A.H. Bhuiyan, S. Khandaker, comparative study of chemically and mechanically singed knit fabric, International Journal of Research in Engineering and Technology, Vol:3, issue: 3, march 2014, pp: 675-679.

[2] S. Yesmin, M. Hasan, M.S. Miah, F. Momotaz, M.A. Idris, M.R. Hasan, Effect of stitch length and fabrics constructions on dimensional and mechanical properties of knitted fabrics, World Applied Sciences Journal, 32 (9), 2014, pp:1991-1995.

[3] L. Li, M. Zhu, X. Wei. Pilling Performance of Cashmere Knitted Fabric of Woolen Ring Yarn and Mule Yarn, FIBRES \& TEXTILES in Eastern Europe 2014; 22, 1(103): pp: 74-75.

[4] N. Özdil, E. Özdogan, A. Demirel, T. Öktem. A Comparative Study of the Characteristics of Compact Yarn-Based Knitted Fabrics. Fibres \& Textiles in Eastern Europe 2005; 13: pp: 3943.

[5] D. Gintis, and E. J. Mead, The Mechanism of Pilling, Textile Research Journal, 29(7), 1959, pp: 578-585.

[6] R. Campos, T. Bechtold, Fiber Friction in Yarn - A Fundamental Property of Fibers, Textile Research Journal, 73(8), 2003 pp: 721-726.

[7] B. U. Nergis, C. Candan; Properties of Plain Knitted Fabrics from Chenille Yarns, Textile Research Journal, 73(12), 2003, pp: 1052-1056.

[8] S. Mavruz, R. T. Ogulata; Knitting World Magazine, 22, 2007, pp: 60-65.

[9] E. Baird, P. Hatfield \& G. J. Morris, A Study of Nylon and Nylon blended fabrics, Journal of the Textile Institute, 47(3), 1956, pp. 181-201.

[10] O Sunay, U Sukriye, An Investigation about Tensile Strength, Pilling and Abrasion Properties of Woven Fabrics Made from Conventional and Compact Ring-Spun yarns, Fibres \& Textiles in Eastern Europe, 1 (60), 2007, pp. 39-42. 